\title{
Religious Support as a Contribution to Face the Effects of Social Isolation in Mental Health During the Pandemic of COVID-19
}

\author{
Cláunei C. D. Dutra ${ }^{1} \cdot$ Henrique S. Rocha ${ }^{1} \odot$
}

Accepted: 19 November 2020 / Published online: 6 January 2021

() Springer Science+Business Media, LLC, part of Springer Nature 2021

\begin{abstract}
Coping with the COVID-19 pandemic has required measures to contain the contagion, including social isolation. However, this and other factors have caused mental health problems, both in patients and health professionals and in family members or asymptomatic population. Religious support can be an ally for this type of confrontation. In the case of the COVID-19 pandemic, spiritual/religious care has been restricted and insufficient. When accessible to patients and frontline professionals, they are offered by virtual means, almost always by recorded media and made available in bulk. This essay argues, based on references in the areas of psychology, psychoneuroimmunology, biosafety, and military, that the face-to-face and personalized relationship between religious leaders, patients, health professionals, family members, and faith communities is as essential as possible for the dignified treatment victims, referral to spiritual needs and resilience of society, in addition to contributing to the improvement of the immune response of all. Practical examples are cited in the areas of military chaplaincy and hospital civilian chaplaincy. The essay also proposes the adoption of protocols already published by WHO and other safety measures such as the use of robotics and the recruitment/training of mass chaplains. In addition to contributing to the improvement of COVID-19 pandemic coping processes, the study also contributes to improving the delivery of spiritual/religious care as an ally to physical and mental, individual, and collective health.
\end{abstract}

Keywords Coronavirus infections · Pastoral care $\cdot$ Mental health $\cdot$ Containment of biohazards $\cdot$ Military activities

Disclaimer This article is not intended to be a recommendation for practice and/or a guideline for action, but to serve as a scientific-academic review of existing knowledge about the provision of spiritual care in a crisis such as COVID-19. Practitioners must follow their local rules, regulations, and policies.

Henrique S. Rocha

rochahsr@fab.mil.br

1 Aerospace Sciences Postgraduate Program, Universidade da Força Aérea, Av. Marechal Fontenelle, 1000 - Campo dos Afonsos, Rio de Janeiro, RJ 21740-002, Brazil 


\section{Introduction}

The COVID-19 pandemic, as declared by the World Health Organization (WHO) on March 11, 2020 (Ghebreyesus 2020), has caused thousands of deaths around the world. The accelerated contagion and the need to avoid the collapse of the capacity to provide health services has required government authorities to enact measures of isolation and social distance. COVID-19 patients have extremely limited social contacts. Ethical issues come up in the face of the need for screening in the supply of breathing apparatus. Exaggerated sanitary measures adopted by local authorities prevent physical or visual contact from family members even though guidelines on the subject have already been issued by WHO. The severity of this situation has impacted the mental health of hospitalized patients, health professionals, family members, individuals in isolation at home, and the population in general. Given the facts, this academic essay warns of the need to use spiritual and religious care as a contribution to coping with the effects of COVID-19. Resilience in coping with trauma, seeking meaning, spiritual comfort, and reducing the possibilities of compromising the mental and physical health of those involved, and the population in general are some of the benefits. Proposals are made for safe procedures for the provision of religious services directed to the asymptomatic population and to the people directly or indirectly affected by COVID-19 based on protocols of religious support in environments of chemical, biological, radiological, and nuclear contamination (CBRN) already developed by US military forces. This academic essay also makes references to examples already implemented both in religious support to the military and in what is offered in the environment civil hospital, which can contribute to reflections on the best practices of this type of assistance. The studies referenced in the areas of psychology, psychoneuroimmunology, among others, leave no doubt that the adequate confrontation of the COVID-19 pandemic cannot do without the resource of religious support, which can bring comfort and discernment to help prevent the emergence of effects to mental health and its consequent impacts on the physical health of the patients themselves, the professionals involved and the population in general.

\section{Religious Support in Traumatic Events: An Ally of Health Services}

The Army National Guard (2014) thus characterizes a traumatic event:

An event is considered potentially traumatic when it causes individuals or groups to experience intense feelings of terror, horror, helplessness and/or hopelessness. Guilt, anger, sadness, and a shift in worldview or faith are possible emotional/cognitive responses to PTEs. (p. 159).

Ritchie (2004), when reflecting on best practices in the field of mental health in the face of CBRN attacks, is categorical in stating that there will be psychological sequelae. In this sense, he cites the importance of the participation of religious 
leaders and spiritual counselors for the treatment of trauma. Ippolito et al. (2006) highlighted the importance of the participation of spiritual counselors in multidisciplinary planning and assistance teams in hospitals that care for victims of bioterrorism or contagious diseases. Among the spiritual factors of psychological effects caused by a traumatic event are changes in how the affected individual believes that life should be lived on a daily basis, changes in belief in God, and changes in acceptance and understanding between good and bad (Lemyre et al. 2005). A study of young adults in Poland during the COVID-19 pandemic pointed to the occurrence of negative mental health symptoms, related to the loneliness of social isolation and the expectation of probable financial problems. It was concluded that "the lack of important social ties can reduce someone's motivation to minimize the risk related to the disease" (Okruszek et al. 2020, p. 16). Studies carried out in the field of psychoneuroimmunology have demonstrated the direct relationship between emotional factors and the immune system (Maia 2002). Even with regard to the immune response of patients who are victims of several influenza viruses, it has been shown that those patients who have a greater social relationship are less likely to develop severe symptoms, while social isolation is considered to be a factor affecting the immune system (Cohen et al. 1993). According to House et al. (1988; as cited in Maia 2002, p. 215), "The effect of social isolation in terms of health is comparable to the effect of other risk factors such as smoking, blood pressure, blood lipids, obesity, and physical activity." Koenig and Cohen (2002, p. 22), when linking several studies on the relationship between religion and health, pointing to a probability of a religion positively influencing the immune system, consequently, physical health, through stress reduction: "By providing a more positive, optimistic worldview, religion may improve coping with acute or chronic stress, thereby ameliorating the effects that the stress has on the immune system." One of the aggravating factors of the respiratory infection caused by the SARS-CoV-2 virus is precisely the patient's low immunity. Religious support has the ability to establish connections, not only between patients and their beliefs, but also between patients and their faith and family communities. WHO considers religious leaders "to be the main source of support, comfort, guidance, direct health care, and social service to the communities they serve" (World Health Organization 2020b, p. 1). Given this, there is a need for victims of traumatic events such as the pandemic of COVID-19 to be accompanied also by professionals in the religious area in order, not only to contribute to mental health but also to the health system itself, since the improvement of the immune system's response to infections would make it possible to reduce the length of hospital stay. The challenge is how to offer religious support in order to prevent further contagion. To facilitate the delivery of this type of assistance, it is important to distinguish the characteristics of religious support.

\section{Characteristics of Religious Support in Traumatic Events}

Religious Support or Chaplaincy are commonly characterized as Religious Care, Spiritual Care, or Religious Advisement. Religious Care is more related to rituals that seek the reconnection of the victim with God or with his beliefs and values. In 
this assistance, there is a well-defined dogmatic identification. They are well-established rites, operated almost exclusively by religious leaders and generally marked by forms and objects of worship. It usually finds it difficult to perform in an environment with a high risk of contamination because it often uses objects of worship such as, for example, "anointed oil," "holy water," "sacred herbs," printed literature, vestments, sculpture images, or rites and procedures specific to each denomination/ religion, such as bathing, physical touching, sharing symbolic/consecrated foods, among others. Spiritual Care is the development of individualized religious support activities related to accompaniment and emotional support, also aiming at reconnecting with spiritual beliefs and values, but without necessarily using forms and objects of worship. They are provided by religious leaders but also by trained health professionals and are aimed, among other things, at encouragement, comfort, confidence, hope, resilience, and strengthening of faith. This differentiation is made clear in the Manual of Spiritual Care of the National Health Service (NHS) Education for Scotland (2009):

Spiritual Care, usually provided in an individual relationship, is completely person-centered and makes no assumptions about personal belief or life orientation. Religious Care is provided in the context of the religious beliefs, values, liturgies, and lifestyle of a community of faith. Spiritual Care is not necessarily religious. Religious Care at its best should always be spiritual. (p. 21)

Religious Advisement is directed to managers and health professionals about religious aspects that impact the treatment of infected patients. About this, Carter and Amlôt (2016) observed some complicating factors:

A key issue that can go against religious and cultural values is to undress in front of others. Therefore, it is crucial that every effort is made to maintain the privacy and dignity of those affected; this is true for everyone, not just for those with different religious and cultural values. (p. 18)

The presence of religious leaders in the hospital team should contribute to clarifying these aspects, include in bioethical decisions regarding the screening of patients.

For all types of religious support, it is essential that religious leaders receive adequate training in protection actions, safe care protocols, use of personal protective equipment (PPE), and decontamination procedures. Military and civil organizations with experience in support and remediation actions at events CBRN are a reference for the development of this type of training, both for military chaplains and for religious leaders and civil chaplains.

\section{Examples of Military Chaplaincy}

The United States Air Force (USAF) issued on June 17, 2019, Air Force Instruction (AFI) 52-104 (Secretary of The Air Force 2019) guiding the operational employment of its chaplains, including at CBRN events. Although the document specifies that the religious support team should not take unnecessary risks, it admits Spiritual Care within a protected collective environment, in an area at risk of contamination, 
using appropriate personal protective equipment according to the level of contamination. The USAF's core doctrine on weapons of mass destruction operations guides the provision of Spiritual Care in consideration of the trauma caused by the psychological impact of CBRN contamination events and recommends that these professionals be continually trained and included in the planning of operations for disaster management consequences of CBRN events (Curtis E. Lemay Center for Doctrine Development and Education 2016). These chaplains participate in training for CBRN Defense operations lasting 20 months. In addition, it has the duty to keep the personal CBRN ensemble always ready and available for use (United States Air Force Chaplain Corps 2008).

In Brazil, the reference on the employment of the military chaplain in CBRN Defense is the EB70-MC-10.240, Campaign Manual "Assistência Religiosa em Operações" (Religious Support in Operations) of the Exército Brasileiro (Brazilian Army), which restricts religious support to the uncontaminated area, with a view to offer comfort to those present and "provide due religious assistance to the dead" (Comando de Operações Terrestres 2018, p. 28). Within the scope of the Força Aérea Brasileira-FAB (Brazilian Air Force), studies are being carried out at the Universidade da Força Aérea-UNIFA (University of Air Force)—in order to propose more effective measures for the performance of its Religious Service in CBRN Defense and other traumatic events.

\section{Challenges and Proposals for Religious Support in Addressing the COVID-19 Pandemic}

In the context of social isolation, voice and image communication resources have played a fundamental role in maintaining social ties. How does religious support fit in this context? Would virtual contact replace physical presence? It is observed that there are both opportunities and challenges for effective religious support in the context of confronting COVID-19.

\section{Religious Support for Patients Hospitalized with COVID-19 and Their Families}

WHO recognizes the role of religious leaders in confronting COVID-19 by promoting mental health, well-being, and resilience through personal contact (with protective measures) and virtual contact via social media and other electronic means (World Health Organization 2020b). In Brazil, the Ministério da Saúde (MS) (Brazilian health organization) instructed local health services to suspend visits to patients affected by COVID-19, although it did not issue specific guidelines for the performance of religious services in hospitals (Departamento de Atenção Hospitalar, Domiciliar e de Urgência 2020). Although many hospitals have canceled chaplaincy activities because of the risk of contagion from COVID-19, others have maintained chaplaincy activities with the necessary safety recommendations. 


\section{Examples of Face-to-Face Religious Support}

The Associação de Capelania em Saúde (ACS) is an evangelical religious entity that coordinates hospital chaplaincy activities in 10 hospitals in the State of São Paulo (Brazil), including the Instituto de Infectologia Emílio Ribas. On the role of ACS in the context of the COVID-19 pandemic, Eleny Vassão Aitken, General Director of the entity, declared in a letter-report addressed to the maintainers:

In mid-March we had to withdraw from the chaplaincy work in hospitals, at the request of their Directors, for protection and also for saving masks, gloves, and aprons, already so scarce, for the use of health professionals on the front lines of the battle against Coronavirus. About 10 days ago, some of the directors and many health professionals in these hospitals cried out for us, as they were tired of looking after so many sick people in an emergency and very mentally and spiritually worn out, in the face of so many concerns about the dangers of contamination of their patients. family members, and themselves. Our Teams are back in hospitals, in a reduced way, and respecting all the guidelines of the Ministério da Saúde, giving special attention to Health Professionals, through devotionals called MINUTES WITH GOD, and also in contact with the patients' relatives, who are distressed and unable to visit them. Precious moments of spiritual singing have also been brought to patients in the corridors and daily sending of recorded messages by our chaplains and visitors, which has eased the burden and stimulated the faith of those who are suffering more closely from the pandemic. (E.V. Aitken, personal communication, May 7, 2020).

In addition, the ACS chaplains participate in daily meetings of Palliative Care Teams in order to collaborate with decisions related to bioethics (E.V. Aitken, personal communication, May 7, 2020).

From Italy, one of the countries most affected by the pandemic, Father Giovanni, chaplain at the Hospital Polivalente Luigi Sacco, in Lombardy, reported his experience in an interview with the Rádio Renascença (Frazão and Miguel 2020), when visiting patients with COVID-19:

Can you talk to the sick? Today, I met 14 COVID patients who had asked to meet me. Most wanted to receive communion. What feelings do they express to you? Everyone is afraid. But, on the other hand, all the people I met today were moved. They were moved by the fact that I was there [emphasis added], even a person who declared himself not a practitioner, not a believer, when he saw that I had gone to find his roommate to give him communion, asked me for the blessing and he accepted to pray a prayer with us. All this can only last, three to five minutes, it is the maximum time to be in each room. Do you usually take Holy Unction to the sick? I go there, when asked, I administer it to the sick and I bless the whole room. The last was yesterday, to the father of a doctor who works at the hospital. What about funerals? When family members contact the chaplaincy, I celebrate as I can, in an empty square, next to the coffin. I say a few prayers and bless 
the coffin before they take it to the cemetery. Here, there is no longer the usual burial apparatus, according to Christian tradition. But the Church is still present. [Emphasis added].

As can be seen, fear is the common feeling that leads the sick to ask for the prayers and services of the religious, but the presence of the chaplain brings comfort.

The Swiss Association for Palliative Medicine, Care and Support, Palliative ch, created a task force to confront COVID-19 involving medical representatives, nurses, and religious professionals in order to minimize the effects of anxiety, including in the decisions that involved screening in the treatment, where religious professionals actively participate offering Spiritual Care, including in the grief of families (Domenico et al. 2020).

The military chaplain of the Exército Brasileiro (Brazilian Army) 1st Lt Edson Silva, pastor chaplain of the Comando do Grupamento de Unidades Escola - $9^{a}$ Brigada de Infantaria Motorizada (GUEs - $9^{a}$ Bda Inf Mtz) and Guarnição da Vila Militar in Rio de Janeiro, in personal testimony, stated:

I could see how much the pastoral visit of the chaplaincy brought a certain comfort and spiritual comfort. For one of the hallmarks of COVID-19 is that in addition to the struggle with the symptoms and effects of the disease, some people had depressed and sad feelings with the issue of isolation. [...] Spiritual and religious support is very important [...] both for the patient and for the teams of doctors, nurses, and general services in hospitals [who] deal with strong emotional pressure all the time. (E. Silva, personal communication, May 4, 2020).

Face-to-face religious support contributes to emotional support for health professionals. Many of these are exhausted with the intense pace of care or in ethical dilemmas due to decisions regarding the screening of patients. Chaplains can participate in meetings with these professionals during their rest breaks or after the end of the working hours, in addition to participating in the Bioethics teams (Roser et al. 2020).

In the US military chaplaincy, there is a concept known as the ministry of presence, where only the physical presence of the chaplain, not necessarily the service, is already capable of transmitting comfort. On this, Tinsley (2013) states:

The ministry of presence affirms that the military chaplain's presence among his troops encourages hope for the future and comfort for the present, fosters a realization of the genuine presence and providence of God [...] Indeed, it is the physical, emotional, and spiritual presence of the chaplain that actuates efficacy in ministry. (p. 9)

Therefore, there is a need for hospital managers to provide means for patients with COVID-19 to receive face-to-face or virtual spiritual and religious care in real time. Such provision is both a humanitarian and preventive measure because, in addition to dignifying the patient in their beliefs, it can prevent the disease from worsening due to causes related to mental health and make frontline professionals (doctors, nurses, etc.) more resilient to carry out their tasks. 


\section{Robotics and Recruitment: Possibilities for Religious Support}

In view of the possible scarcity of chaplains for face-to-face demand, virtual religious support is a possibility. However, electronic media must allow chaplains and patients to interact in real time so that the mechanisms of spiritual/religious care can be delivered in a personalized way and adapted to the patients' momentary needs. Thus, the technology can be used with more humanization and socialization, without prejudice to the patient's perception of spiritual/religious care. In this sense, in addition to the use of personal electronic devices, robotics can be used for building a system virtual contact with a real-time patient without the risk of contamination to the chaplains: voice and image transmission devices taken to bed by robots connected to a central religious support where chaplains trained to manage the system, give individual messages or blessings live and broadcast religious ceremonies virtually to the patient, also enabling connection with family and friends. In this way, chaplains could serve more patients in personalized and live communication, with less physical wear, no risk of contagion, without prejudice to medical treatment and greater focus on the patient being treated, that is, less risk of distractions if compared to face-to-face assistance. If there is a need for emergency medical care during spiritual/religious assistance, the chaplain can call the medical team by an electronic signal from his position, without the need to lose contact with the patient. For that, it is necessary to create performance protocols, production of adapted robots, provision of media devices, and system management structure. A prototype of this system is being developed in Brazil at the Universidade da Força Aérea-UNIFA. Evidently, systems like this would not be available to all patients who need spiritual/ religious care.

Therefore, another suggested measure, at the government level, is that volunteer religious professionals be registered and trained, similarly to what was done by the MS (Brazil) with the call for health professionals through Ordinance No. 639 of March 31, 2020 (Gabinete do Ministro 2020), to offer spiritual/religious care to COVID-19 patients in hospitals that do not have an organized religious service or the possibility of implementing a robotic system. This summons may even form a database for future actions in the event of tragedies and other mass events.

\section{Funeral Ceremonies for Victims of COVID-19}

The post-mortem religious ritual is considered fundamental for coping with grief. At funerals whose deceased have been contaminated with COVID-19, considerations of respect for religious rituals have been challenged. The WHO recognized the need to offer dignified treatment to the dead and family members in line with their beliefs (World Health Organization 2020a). In Brazil, although does not recommend funerals for confirmed or suspected patients with COVID-19, the MS (Departamento de Análise em Saúde e Vigilância de Doenças não Transmissíveis 2020) advises family members, if the funerals are held, to adopt safety measures:

Keep the funeral urn closed during the entire viewing and funeral, avoiding any contact (touch/kiss) with the body of the deceased at any post-mortem 
moment; Provide water, soap, paper towels and 70\% gel alcohol for hand hygiene throughout the wake; Make the urn available in an open or ventilated place; Avoid, especially, the presence of people who belong to the risk group for worsening COVID-19: age equal to or above 60 years, pregnant women, lactating women, those with chronic diseases and immunosuppressed; Do not allow the presence of people with respiratory symptoms, observing the legislation regarding quarantine, and compulsory hospitalization within the scope of the Public Health Emergency of National Importance (ESPIN) by COVID19; If it is essential, they must wear a common surgical mask, stay as little as possible in the location and avoid physical contact with others; Do not allow the provision of food. For drinks, the measures of not sharing glasses must be observed; The burial ceremony should not include a crowd, respecting the minimum distance of at least two meters between them, as well as other measures of social isolation and respiratory etiquette; It is recommended that the burial takes place with a maximum of 10 people, not because of the biological risk of the body, but because of the contraindication of agglomerations. Deceased due to COVID-19 can be buried or cremated. (p. 14)

Another interesting suggestion given the insufficient number of religious leaders to assist the bereaved is the support of spiritual counseling groups, guided and coordinated by religious leaders (Roser et al. 2020). According to Silva and Alves (2020), in the context of the COVID-19 pandemic, there should be no funerals (long duration), but only funeral services (short duration) restricted to some people closest to the deceased, or broadcast live over the internet. One suggestion is to place the funeral urn in an open or ventilated place, separated by a glass or acrylic structure, in order to avoid physical contact with the funeral urn, but preserving visual contact. This would help to prevent not only the spread of the virus but also excesses motivated by the emotion of family members when approaching the funeral urn. Certainly, there are included all other protective measures, among the family members and friends present, already listed.

\section{Religious Rites and Ceremonies for Asymptomatic Society}

WHO issued considerations and recommendations to religious leaders and communities of faith about their performance during the COVID-19 pandemic period (World Health Organization 2020b). The document makes clear the importance of the role of religious leaders in directing public health policies to communities and recognizes that religious services are essential to promote safe information, prevention, and reduction of fear in the population. Even if the adoption of electronic means for the delivery of the religious service is suggested, WHO does not rule out the possibility of face-to-face celebrations as long as in agreement with local, regional, or national government authorities. However, it establishes several safety parameters for such celebrations. The following recommendations are: (a) maintain a minimum distance of $1 \mathrm{~m}$ at all times between people; (b) prevent physical contact between participants; (c) prevent contact with other objects of worship that are usually shared during ceremonies; (d) encourage healthy hygiene habits at all meetings; 
and clean the places of worship, seats, and buildings frequently; (e) inform participants about the flow of people through worship spaces using signs and notices visible to all; and (f) when possible that face-to-face celebrations take place in an open environment or, when this is not possible, in a ventilated environment (World Health Organization 2020b).

In Brazil, despite the fact that there are open-air ceremonies, the result of the creativity of religious leaders, where the faithful are served in their cars for Catholic confession, for example, it is still a challenge to hold face-to-face religious ceremonies. There are still many religious communities without access to technological means, whether for technical or financial reasons, who also suffer from the effects of social isolation. To meet these challenges, there is a need for protocols to prevent the spread of COVID-19. The Government of the State of Goiás (Brazil) has initiated a procedure in this regard. On April 19, 2020, it issued Decree No. 9653 (Atos do Poder Executivo 2020) authorizing religious organizations to hold face-toface meetings respecting certain rules. Among them are the occupation of a maximum of $30 \%$ of the temple's capacity, the observation of hygiene, the obligation to use masks, and the distance between the participants. The Government of the State of Santa Catarina (Brazil) has taken similar and even more detailed measures, in accordance with Ordinance SES No. 254 of April 20, 2020 (Secretaria de Estado da Saúde 2020), standardizing even the celebrations that involve handling food during the celebrations. The prior scheduling of the presence of believers considering the maximum number of places must be adopted.

All of these measures are subject to review; however, the understanding that religious support is an essential activity in the context of the COVID-19 pandemic is fundamental for prevention in relation to society's mental health.

\section{Conclusion}

In the face of the global crisis brought about by the COVID-19 pandemic, many protective measures are necessary to avoid the population becoming ill and the worsening of the crisis even in economic terms. Every effort to contain the spread of the SARS-CoV-2 virus needs to be undertaken. However, the measures adopted by the countries need to take into account a broader spectrum, in addition to the sanitary measures to contain the spread. It is also necessary to assess the impacts of these measures on the mental health of the population. It is clear that isolation and social detachment are effective from the health point of view, in order to prevent the collapse of health systems; however, such measures must be accompanied by processes of promotion of mental and spiritual health that aim to minimize psychological damage in citizens and families. In addition, it is necessary to undertake or reinforce a culture of human dignity where fundamental values are preserved in order to maintain an organized and healthy society in all aspects. In this scenario, governments, whether national, state, or municipal, should not fail to offer populations options to meet their spiritual and social needs. Examples such as the USAF military chaplaincy serve as a reference for the development of similar religious support programs, both in the context of military chaplaincy and hospital civilian chaplaincy. 
Technological advances in the areas of robotics and image and sound transmission have provided a lot of resources in the search for social contact, which makes Pandemia COVID-19 different, in this aspect, from other past pandemics. However, technology is not available to everyone and, by itself, does not fully satisfy people's spiritual needs. Therefore, it is urgent that measures be taken to promote safe socialization and religious support, even among asymptomatic citizens. The proposals presented above represent a reflection on the use of religious support resources with a view to the contribution of religious entities in addressing the effects of COVID19. These resources are, almost always, of low cost to the governments, but they can represent a great benefit for the populations, under aspects of spiritual, mental, and physical health that, consequently, will result in benefits for other areas, including for the areas of public security and the economy. In this sense, it is concluded that the use of religious support is essential in facing the pandemic of COVID-19.

Acknowledgements This study was financed in part by the Coordenação de Aperfeiçoamento de Pessoal de Nível Superior-Brasil (CAPES)—Finance Code 001 (Grant No. 8887.285949/2019-20).

\section{References}

Army National Guard. (2014). Chaplain Corps (ARNG) Handbook. Fort Leavenworth: Training Analysis Feedback Team (TAFT). Retrived May 01, 2014, from, https://usachcstraining.army.mil/ documents/71891/0/Chaplain+Corps+ARNG++Handbook.pdf/a3cf66a1-9a72-4fc7-8abe-a44d0 fa57c9a

Atos do Poder Executivo. (2020, April 19). Decreto no 9.653, de 19 de abril de 2020. Dispõe sobre a decretação de situação de emergência na saúde pública do Estado de Goiás, em razão da disseminação do novo coronavírus COVID-19. Diário Oficial Estado de Goiás, 183(23284). Retrived from, http://www.diariooficial.abc.go.gov.br/portal/edicoes/download/4188.

Carter, H., \& Amlôt, R. (2016). Mass casualty decontamination guidance and psychosocial aspects of CBRN incident management: A review and synthesis. PLoS Currents. https://doi.org/10.1371/ currents.dis.c2d3d652d9d07a2a620ed5429e017ef5.

Cohen, S., Tyrrell, D. A. J., \& Smith, A. P. (1993). Negative life events, perceived stress, negative affect, and susceptibility to the common cold. Journal of Personality and Social Psychology, 64(1), 131-140. https://doi.org/10.1037/0022-3514.64.1.131.

Comando de Operações Terrestres. (2018). Manual de Campanha EB70-MC-10.240 A Assistência Religiosa nas Operações (Portaria No 134-COTER). Ministério da Defesa, Exército Brasileiro. Retrived November 27, 2018, from, https://bdex.eb.mil.br/jspui/bitstream/123456789/2652/1/ MC\%20Assistencia\%20Religiosa\%20EB70-MC-10.pdf.

Curtis E. Lemay Center for Doctrine Development and Education. (2016). Annex 3-40 Counter Weapons of Mass Destruction (WMD) Operations, Appendix B: Consequence Management. U.S. Department of The Air Force. Retrived April 5, 2016, from, https://www.doctrine.af.mil/Porta 1s/61/documents/Annex_3-40/3-40-D15-CBRN-App2-Consequence.pdf.

Departamento de Análise em Saúde e Vigilância de Doenças não Transmissíveis. (2020). Manejo de corpos no contexto do novo coronavírus COVID-19. Ministério da Saúde, Secretaria de Vigilância em Saúde. Retrived March 25, 2020, from, http://www.saude.gov.br/images/pdf/2020/marco /25/manejo-corpos-coronavirus-versao1-25mar20-rev5.pdf.

Departamento de Atenção Hospitalar, Domiciliar e de Urgência. (2020). Protocolo de Manejo Clínico da Covid-19 na Atenção Especializada. Ministério da Saúde, Secretaria de Atenção Especializada à Saúde. Retrived March 25, 2020, from, https://bvsms.saude.gov.br/bvs/publicacoes/manej o_clinico_covid-19_atencao_especializada.pdf.

Domenico, B. G., Claudia, G., Monika, O., \& Ralf, J. (2020). COVID-19: Decision making and palliative care. Swiss Medical Weekly, 150, w20233. https://doi.org/10.4414/smw.2020.20233. 
Frazão, J.P., \& Miguel, A. (2020, March 24). Combate ao coronavírus. A vida de um capelão num hospital em Itália [Radio broadcast transcript]. Rádio Renascença. Retrived from, https://rr.sapo. pt/failover.aspx ?aspxerrorpath=/2020/03/24/religiao/combate-ao-coronavirus-a-vida-de-umcapelao-num-hospital-em-italia/noticia/186583\%20/.

Gabinete do Ministro. (2020, April 2). Portaria n 639, de 31 de março de 2020. Dispõe sobre a Ação Estratégica "O Brasil Conta Comigo - Profissionais da Saúde", voltada à capacitação e ao cadastramento de profissionais da área de saúde, para o enfrentamento à pandemia do coronavírus (COVID-19). Diário Oficial da União, 64(1). 76. Ministério da Saúde. Retrived from, http:// www.in.gov.br/en/web/dou/-/portaria-n-639-de-31-de-marco-de-2020-250847738.

Ghebreyesus, T. A. (2020, March 11). WHO Director-General's opening remarks at the media briefing on COVID-19-11 March 2020 [Speech transcript]. World Health Organization. Retrived from, https://www.who.int/dg/speeches/detail/who-director-general-s-opening-remarks-at-themedia-briefing-on-covid-19-11-march-2020.

House, J. S. Landis, K. R. \& Umberson, D. (1988). Social relationships and health. Science, 241, 540-545. https://doi.org/10.1126/science.3399889.

Ippolito, G., Puro, V., \& Heptonstall, J. (2006). Hospital preparedness to bioterrorism and other infectious disease emergencies. Cellular and Molecular Life Sciences, 63, 2213-2222. https://doi. org/10.1007/s00018-006-6309-y.

Koenig, H. G., \& Cohen, H. J. (Eds.). (2002). The link between religion and health: Psychoneuroimmunology and the faith factor. Oxford: Oxford University Press.

Lemyre, L., Clément, M., Corneil, W., Craig, L., Boutette, P., Tyshenko, M., et al. (2005). A psychological risk assessment and management framework to enhance response do CBRN terrorism threats and Attacks. Biosecurity and Bioterrorism: Biodefense Strategy, Practice, and Science, 3(4), 316-330. https://doi.org/10.1089/bsp.2005.3.316.

Maia, A. C. (2002). Emoções e Sistema Imunológico: um olhar sobre a Psiconeuroimunologia. Psicologia: Teoria, Investigação e Prática, 7(2), 209-227.

National Health Service Education for Scotland. (2009). Spiritual Care matters: an introductory resource for all NHS Scotland Staff. U.K. National Health Service. Retrived September 27, 2020, from, http://www.elament.org.uk/media/1209/spiritualcaremattersfinal.pdf.

Okruszek, L., Aniszewska-Stańczuk, A., Piejka, A., Wiśniewska, M., \& Zurek, K. (2020). Safe but lonely? Loneliness, mental health symptoms and COVID-19. PsyArXiv. https://doi.org/10.31234 /osf.io/9njps.

Ritchie, E. C. (2004). Mass violence and early mental health intervention: A proposed application of best practice guidelines to chemical, biological and radiological attacks. Military Medicine, 164(8), 575-579. https://doi.org/10.7205/MILMED.169.8.575.

Roser, T., Peng-Keller, S., Kammerer, T., Karle, I., Lammer, K., Winiger, F., et al. (2020, March, 30). The Corona pandemic as a challenge for spiritual care. Retrived from, www.covid-spiritualc are.com. https://7b22a723-d18b-4f61-9b60-a0e89eb41dca.filesusr.com/ugd/f9562a_a01f379656 ba450d84ac50658eec880e.pdf.

Secretaria de Estado da Saúde. (2020, April 20). Portaria SES no 254 de 20 de abril de 2020. Diário Oficial SC, 21251. 4-5. Retrived June 17, 2019, from, https://www.sc.gov.br/images/PORTA RIA_SES_254_20_04_2020.pdf.

Secretary of The Air Force. (2019). Air Force Instruction 52-104: Chaplain Corps (HC) Readiness. U.S. Department of The Air Force. Retrived June 17, 2019, from, https://static.e-publishing.af. mil/production/1/af_hc/publication/afi52-104/afi52-104.pdf.

Silva, A. L., \& Alves, G. G. F. (2020). Manual de Ofício Fúnebre: Orientações Técnicas e Litúrgicas para uso durante a Pandemia da COVID-19 e demais situações indicadas. Aliança Evangélica Pró Capelania Militar e de Segurança Pública do Brasil. Retrived April 10, 2020, from, http:// acmeb.org.br/wp-content/uploads/2020/04/ACMEB_ManualOficioFunebre2020.pdf.

Tinsley, M. A. (2013). Service v. presence: implementation of the ministry of service in the military chaplaincy -A receptivity and feasibility study [Doctoral dissertation, Liberty University]. Scholars Crossing. Retrived December 3, 2013, from, http://digitalcommons.liberty.edu/docto $\mathrm{ral} / 780$.

United States Air Force Chaplain Corps. (2008). USAF Chaplain Corps Deployment Guide. U.S. Department of The Air Force. Retrived July 25, 2008, from, https://www.airforcechaplain.com/ wp-content/uploads/2019/02/Chaplain-Corps-Deployment-Guide-25July2008-hires.pdf. 
World Health Organization. (2020a). Infection Prevention and Control for the safe management of a dead body in the context of COVID-19: Interim guidance [fact sheet]. Retrived March 24, 2020, from, https://apps.who.int/iris/handle/10665/331538.

World Health Organization. (2020b). Practical considerations and recommendations for religious leaders and faith-based communities in the context of COVID-19: Interim guidance. World Health Organization. Retrived April 7, 2020, from, https://www.who.int/publications/i/item/ practical-considerations-and-recommendations-for-religious-leaders-and-faith-based-commu nities-in-the-context-of-covid-19.

Publisher's Note Springer Nature remains neutral with regard to jurisdictional claims in published maps and institutional affiliations. 